\title{
Geochronological, Sedimentary, Structural, and Metallogenic Characteristics of Southeast China during the Mesozoic: A General Review
}

\author{
Pengju Li ${ }^{*}$, Hongying $\mathrm{Li}^{2}$ \\ ${ }^{1}$ School of Economics and Management, Sichuan University of Science \& Engineering, Zigong, China \\ ${ }^{2}$ School of the Earth Sciences and Resources, China University of Geosciences, Beijing, China \\ Email: "pengjuli86@163.com
}

Received 29 July 2015; accepted 21 September 2015; published 24 September 2015

Copyright (C) 2015 by authors and Scientific Research Publishing Inc.

This work is licensed under the Creative Commons Attribution International License (CC BY). http://creativecommons.org/licenses/by/4.0/

\section{(c) (i) Open Access}

\section{Abstract}

The tectonic evolution of Southeast China during Late Mesozoic is a prominent topic. Numerous tectonic models on Late Mesozoic evolution of Southeast China have been published in the past 50 years. We synthesized many up-to-date and precise zircon U-Pb ages, sedimentary strata, and regional structures and discussed the oxygen fugacity of magmas and related ore deposits. We also analyzed the most current tectonic models published by some scholars. A multistage tectonic stress evolution history during Late Mesozoic was constructed, which included the following stages: 1) Early-Middle Jurassic (196 - $175 \mathrm{Ma)}$ extension, in which many bimodal volcanics formed; 2) Middle-Late Jurassic (165 - $140 \mathrm{Ma}$ ) compression, which generated largescale gneissic granites, garnet-bearing granites, stratigraphic hiatus, and nappe structures; 3) Early Cretaceous (140 \pm 5 $120 \mathrm{Ma}$ ) extension, which formed weakly deformed or undeformed granites, alkali granites, metamorphic core complexes, graben basins, and basic dike swarms; 4) Early Cretaceous (120 - 110 Ma) compression, which generated nappe structures, volcanic hiatuses, and garnet-bearing granites; and 5) Early-Late Cretaceous (110 - 80 Ma) extension, which generated largescale bimodal volcanics, basic dike swarms, alkali granites, and graben basins. The Late Mesozoic tectonic evolution of Southeast China may be attributed to the drifting history of the Paleo-Pacific plate. The drifting direction of the Paleo-Pacific plate has changed several times since $140 \mathrm{Ma}$, which led to major changes in the tectonicphenomena from Jurassic to Cretaceous and to the formation of Late Mesozoic mineral deposits.

\footnotetext{
${ }^{*}$ Corresponding author.
} 


\section{Keywords}

\section{Tectonic Evolution, Late Mesozoic, Zircon U-Pb Age, Regional Structures, SE China}

\section{Introduction}

The tectonic evolution of Southeast China during Late Mesozoic is a prominent topic. For more than half a century, geologists worldwide have undertaken studies on igneous rocks in Southeast China, and numerous tectonic models on Late Mesozoic evolution of the region were published. These models can be mainly divided into four categories: an active continental margin related to the subduction of the Paleo-Pacific plate, with flat subduction [1] or with a low-angle to a medium-angle subduction [2] [3]; a composite of orogenic belts formed due to continental collisions within the South China block during the Mesozoic period [4]-[6]; rifting along the entire eastern margin of China that commenced in the Middle Mesozoic [7]; and a hot mantle plume in South China block during Mesozoic [8]. Despite the number of studies on this problem, this issue remains unresolved. The reasons for this research gap may be attributed to the use of outdated equipment or the lack of comprehensive study on multiple geological elements. Some traditional dating methods, such as K-Ar and Rb-Sr systems, can be easily disturbed by subsequent hydrothermal events or cannot obtain the exact ages of geologic events. Therefore, a precise and accurate determination of the temporal-spatial distribution of igneous rocks is essential to explore the tectonic evolution of Southeast China. Furthermore, the analysis of sediment and regional structure is required.

This study synthesizes the up-to-date and precise zircon U-Pb ages on the basis of recent studies by our team and other groups. This study also discusses the geological features of Mesozoic basins, nappe structures, angular unconformity, and the oxygen fugacity of magmas and related ore deposits to analyze the plate tectonic setting and petrogenesis of Late Mesozoic igneous rocks. Subsequently, this study reveals the tectonic evolution history of Southeast China during Late Mesozoic.

\section{Temporal-Spatial Distribution of Igneous Rocks}

Igneous rocks are often emphasized by researchers. Zhou and Li [2] suggested that the magmatic activity of the Southeast China continental margin migrated oceanward to the southeast because the slab dip angle of the Paleo-Pacific plate subduction underneath Southeast China increased from low angle to medium angle. Li and Li [1] proposed that the ages of synorogenic magmatism, thrusting, and metamorphism showed a trend of younging toward the cratonic interior during the Permian-Triassic orogeny. They then put forward a flat-slab subduction model. The age of igneous rocks is one of the most critical factors in determining the tectonic evolution of Southeast China. However, some disagreements exist among the ages obtained via different dating methods. Currently, U-Pb dating is accepted as the most accurate dating method available. Therefore, we consulted approximately 1000 papers and collected hundreds of up-to-date U-Pb dating data [87] to reveal the temporal-spatial distribution of igneous rocks during Late Mesozoic. As shown in Figure 1, we conducted statistics on most zircon U-Pb ages of igneous rocks in Southeast China. Basing on the temporal-spatial distribution of these rocks, we did not observe obvious tendency for igneous rocks to grow younger from inland areas toward the coastal areas. Specifically, Jurassic orogeny igneous rocks are distributed throughout both the coastal areas and inland areas (Figure 1), and younger rocks coexist with the older rocks in many areas [9]-[12].

Table 1 and Figure 2 show that the ages of these Yanshanian intrusive rocks can be grouped into four episodes: 196 - 175 Ma (formed diabases, granites and diorite porphyry scattered across Eastern China), 165 - 136 Ma (formed largescale gneissic granites, garnet-bearing granites, and granodiorite), 135 - 120 Ma (formed weakly deformed and undeformed granites, alkali granites, metamorphic core complexes, and some basic dike swarms), and 110 - $80 \mathrm{Ma}$ (formed largescale basic dike swarms, alkali granites, and syenites). The ages of extrusive rocks can be grouped into three episodes: 195 - 177 Ma (formed bimodal volcanics), 145 - 120 Ma (formed felsic volcanics and intermediate-acid volcanics), and 110 - $80 \mathrm{Ma}$ (formed largescale bimodal volcanics).

Magmatic rocks can be used to indicate the setting [46]-[50], such as bimodal volcanics that are generally formed in an extensional tectonic regime. Large-scale volcanic sequences, alkali granites, metamorphic core 


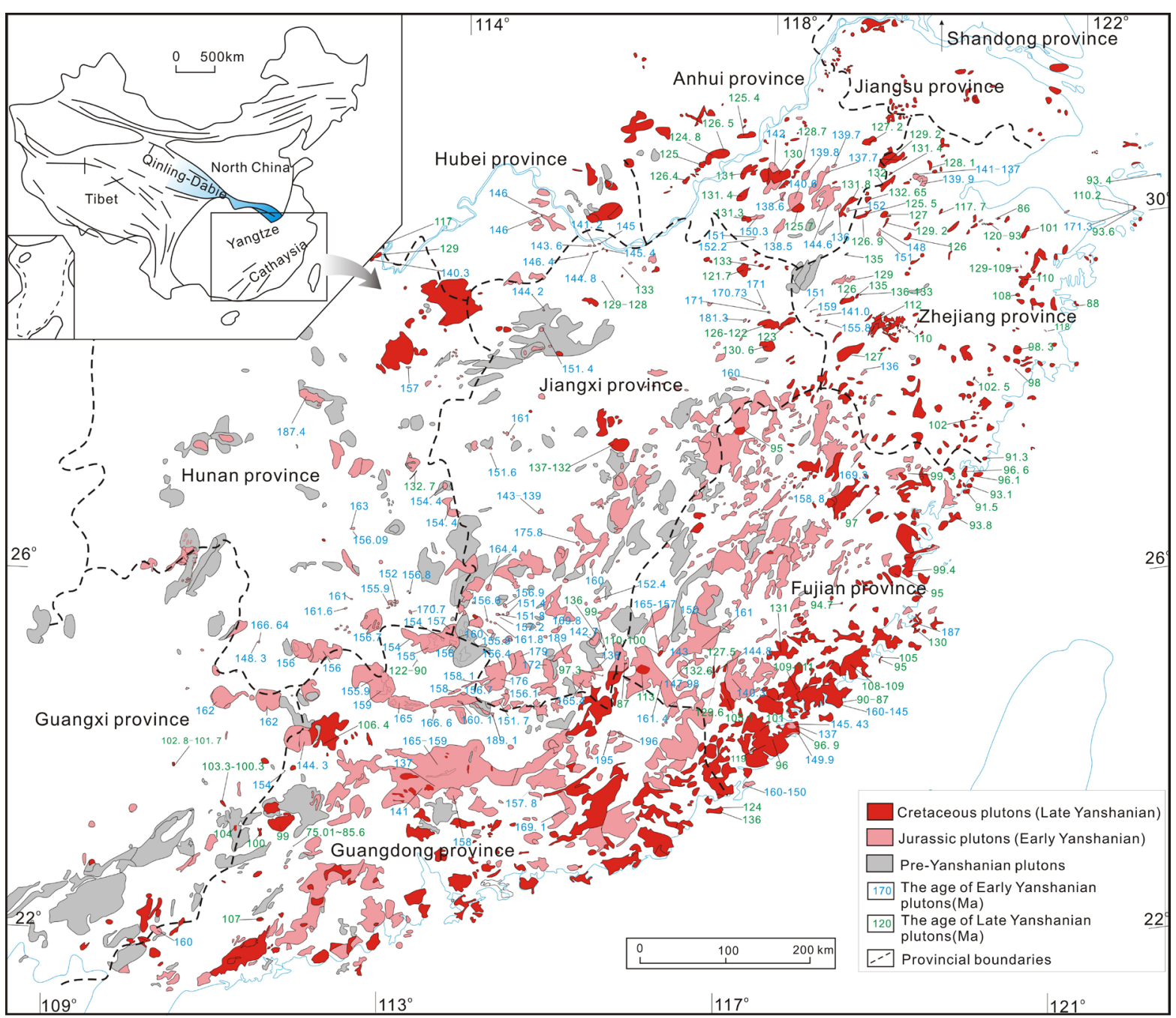

Figure 1. Age distribution of the Yanshanian (200 - 80 Ma) plutons in SE China (The details are shown in [87]).

complexes, and basic dike swarms are the typical products of extensional tectonics [48]. Muscovite, cordierite, garnet-bearing granites, and gneissic granites generally form in syn-orogenic settings [29] [49].

We preliminarily conclude that two compressional and three extensional tectonic events occurred during Yanshanian (200 - 80 Ma): 1) Early-Middle Jurassic (196 - 175 Ma) extension, featured by bimodal volcanics; 2) Middle-Late Jurassic (165 - $140 \pm 5 \mathrm{Ma}$ ) compression, represented by largescale gneissic granites and garnetbearing granites; 3 ) Early Cretaceous ( $140 \pm 5$ - $120 \mathrm{Ma}$ ) extension, characterized by weakly deformed or undeformed granites, alkali granites, metamorphic core complexes, and some basic dike swarms; 4) Early Cretaceous (120 - $110 \mathrm{Ma}$ ) compression, evidenced by volcanic hiatuses during 120 - $110 \mathrm{Ma}$; and 5) Early-Late Cretaceous (110 - $80 \mathrm{Ma}$ ) extension, evidenced by largescale bimodal volcanics, basic dike swarms, and alkali granites.

\section{Stratigraphic Analyses}

Each tectonic event is accompanied by corresponding sediments. The Late Mesozoic stratigraphic sequences in Southeast China show an angular unconformity between Middle Jurassic $\left(\mathrm{J}_{2}\right)$ and overlying Early Cretaceous $\left(\mathrm{K}_{1}\right)$ (Figure 3). Thus, the hiatus of Late Jurassic $\left(\mathrm{J}_{3}\right)$ is general in the study area. The hiatus indicates that Southeast China underwent an intense tectonic event in Late Jurassic when the crust was lifted and eroded. This phenomenon also exists in the adjacent areas, such as Qinling region in North China. This finding suggests that the acme of compression in Eastern China occurred during Late Jurassic. Another angular unconformity occurred between Early Cretaceous $\left(\mathrm{K}_{1}\right)$ and the overlying Late Cretaceous $\left(\mathrm{K}_{2}\right)$ in Southeast China (Figure 3). 

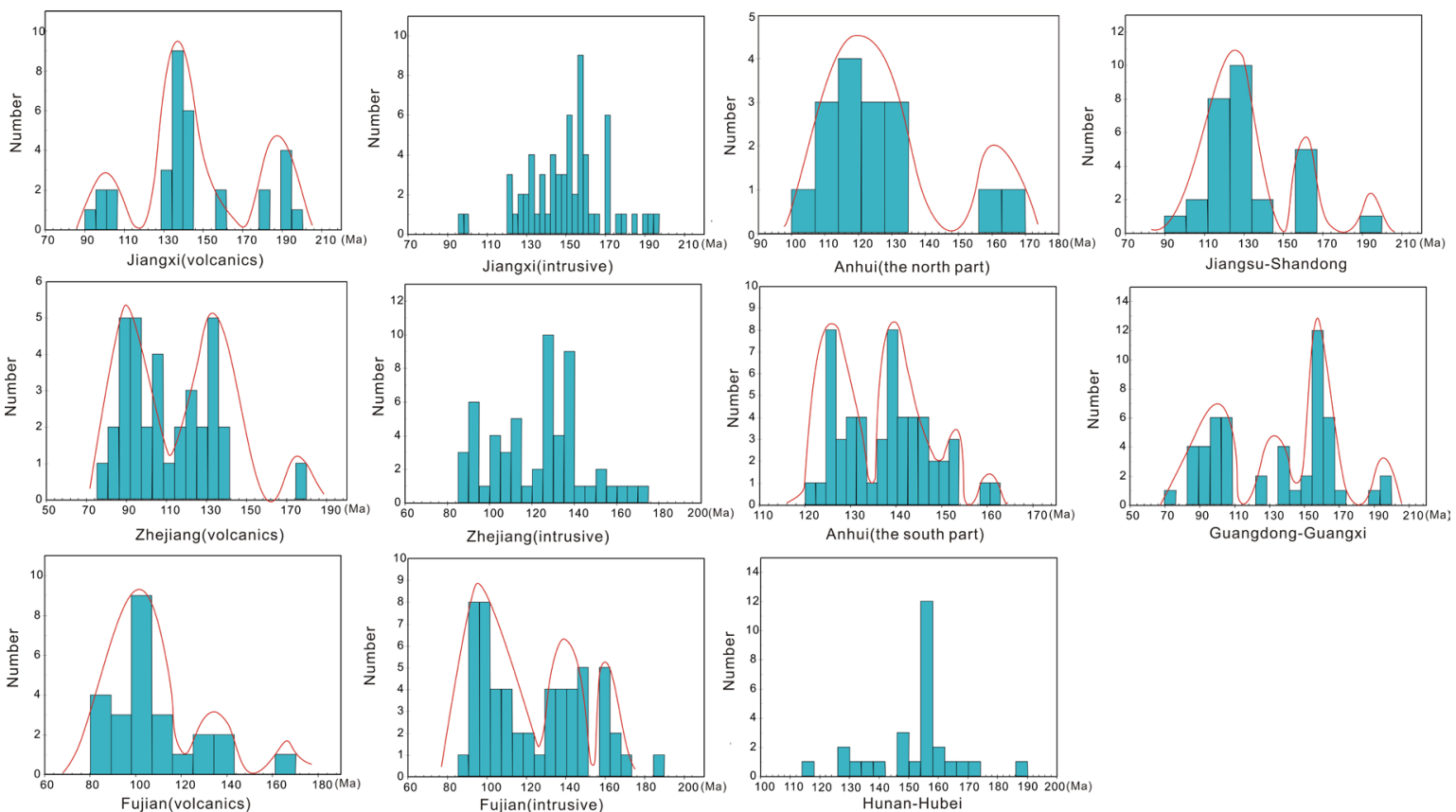

Figure 2. Cumulative diagram of all ages of Yanshanian plutons in ten eastern provinces of China; the diagrams are plotted by CGDK software [13].

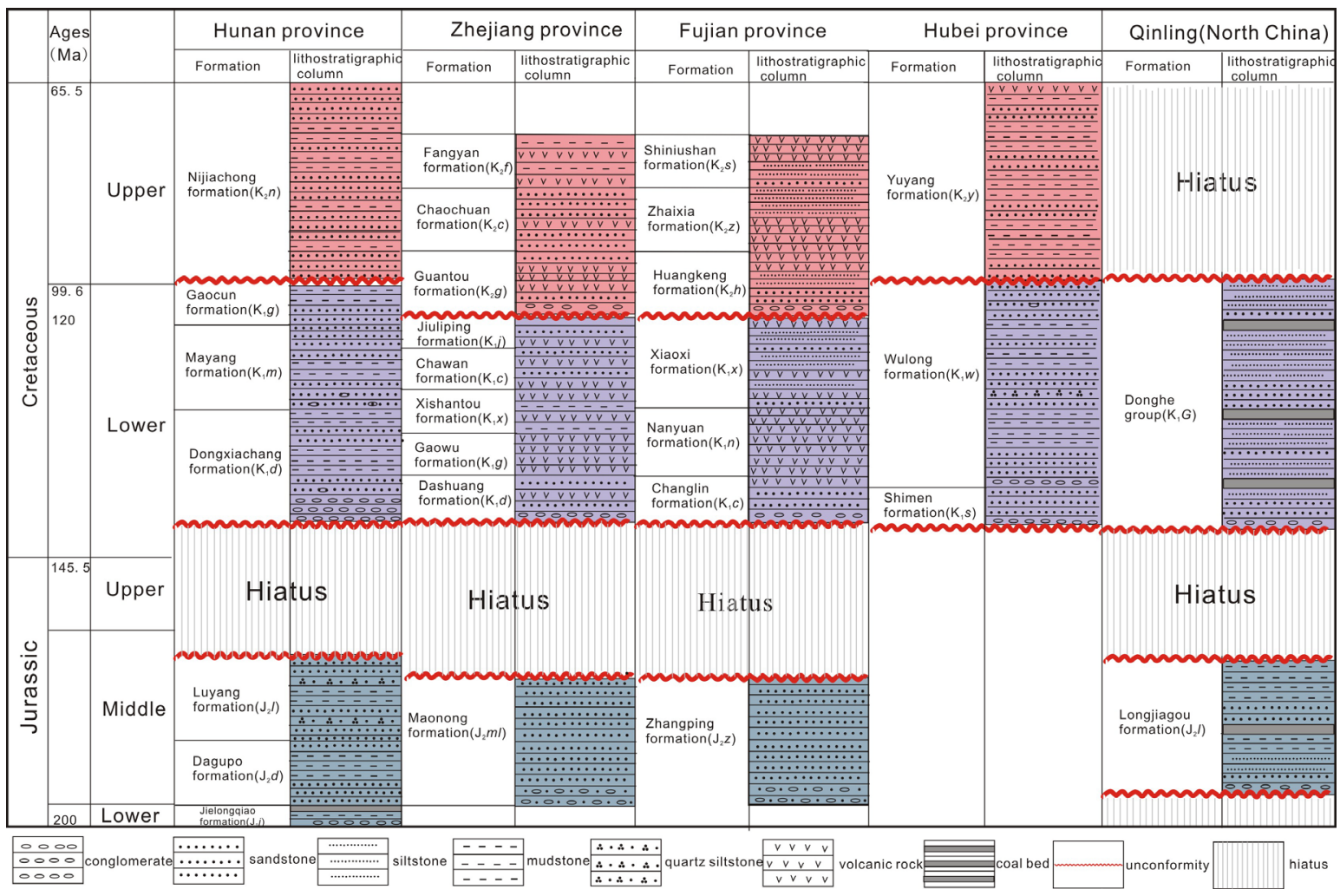

Figure 3. Late Mesozoic regional stratigraphic column in SE China (Stratigraphic column of Hunan and Hubei province from [51]; Fujian province from [43]; Zhejiang province from [36]; Qinling region from [52]).

Compared with the Late Jurassic tectonic movement, the unconformity in Early Cretaceous was smaller. A brief hiatus was identified at 120 - 110 Ma between the lower and upper sedimentary series [36]. 
Table 1. Ages of Yanshanian plutons in Eastern China (The details are shown in [87]).

\begin{tabular}{|c|c|c|c|c|}
\hline Province & Rock types & Typical lithology & Age-bracket & Reference \\
\hline \multirow{3}{*}{ Jiangsu-Shandong } & \multirow{3}{*}{ Intrusive rocks } & Diorite porphyry & $191 \mathrm{Ma}$ & [14] \\
\hline & & Gneissic granite; Monzogranite & 160 - $156.9 \mathrm{Ma}$ & [9] [15] \\
\hline & & $\begin{array}{l}\text { Weakly deformed granite; Undeformed granite; } \\
\text { Alkali granite }\end{array}$ & 135 - 90 Ма & [9] \\
\hline \multirow{3}{*}{ Anhui (the north part) } & \multirow{2}{*}{ Intrusive rocks } & Gneissic granite; Garnet-bearing granite & 165 - 159 Ма & [16] \\
\hline & & Granite & 130.1 - 103 Ма & [17] \\
\hline & Extrusive rocks & Intermediate-acid volcanics & 132 - 116 Ма & [18] \\
\hline \multirow{3}{*}{ Anhui (the south part) } & \multirow{2}{*}{ Intrusive rocks } & Granodiorite & 161.2 - $139 \mathrm{Ma}$ & [10] [19] \\
\hline & & Alkali granite & 136 - $121.8 \mathrm{Ma}$ & [20] \\
\hline & $\begin{array}{l}\text { Metamorphic core } \\
\text { complexes }\end{array}$ & Granodiorite & 126.4 Ма & [20] [21] \\
\hline \multirow{8}{*}{ Jiangxi } & \multirow{3}{*}{ Intrusive rocks } & Diabase; Granite & 196 - 175 Ма & [1] [22] \\
\hline & & Granodiorite porphyry & 170 - $144 \mathrm{Ma}$ & [12] [23] \\
\hline & & Syenogranite & $138-121.7 \mathrm{Ma}$ & [24] \\
\hline & \multirow{3}{*}{ Extrusive rocks } & Bimodal volcanics & 195 - $178.2 \mathrm{Ma}$ & [25] \\
\hline & & Felsic volcanics & $145-128 \mathrm{Ma}$ & [25] \\
\hline & & Bimodal volcanics & 105 - 93 Ма & [26] \\
\hline & \multirow{2}{*}{$\begin{array}{l}\text { Metamorphic core } \\
\text { complexes }\end{array}$} & Granite & $133 \mathrm{Ma}$ & [27] \\
\hline & & Muscovite in the ductile shear zone & $140.4 \mathrm{Ma}$ & [27] \\
\hline \multirow{6}{*}{ Guangdong-Guangxi } & \multirow{3}{*}{ Intrusive rocks } & Granite & 196 - $189.1 \mathrm{Ma}$ & [28] \\
\hline & & Gneissic granite & 169.1 - $136 \mathrm{Ma}$ & [29] \\
\hline & & Weakly deformed granite & 137 - $100 \mathrm{Ma}$ & [29] \\
\hline & \multirow{3}{*}{ Extrusive rocks } & Layered Mafic-Ultramafic rocks & 195 Ма & [28] \\
\hline & & Trachyte & $135.4 \mathrm{Ma}$ & [30] \\
\hline & & Rhyolite & $103-83.4 \mathrm{Ma}$ & [31] \\
\hline \multirow{4}{*}{ Hunan-Hubei } & \multirow{3}{*}{ Intrusive rocks } & Granite & 187.4 Ma & [32] \\
\hline & & Granodiorite & 170 - $146 \mathrm{Ma}$ & [33] \\
\hline & & Monzogranite & 134 - $117 \mathrm{Ma}$ & [34] \\
\hline & Extrusive rocks & Basalt; Dacite & 132 - $128 \mathrm{Ma}$ & [35] \\
\hline \multirow{7}{*}{ Zhejiang } & \multirow{2}{*}{ Intrusive rocks } & Granodiorite & 171 - 139 Ма & [10] \\
\hline & & Syenogranite; Monzogranite & 136 - 86 Ма & [20] \\
\hline & \multirow{3}{*}{ Extrusive rocks } & Tuff & 180 - $177 \mathrm{Ma}$ & [36] \\
\hline & & Tuff; Basalt & $140-120 \mathrm{Ma}$ & [36] \\
\hline & & Bimodal volcanic; Basic dike swarm & $110-83 \mathrm{Ma}$ & [37] \\
\hline & \multirow{2}{*}{ Basic dike swarm } & Mafic rocks & $135 \mathrm{Ma}$ & [38] \\
\hline & & Mafic rocks & $93.4 \mathrm{Ma}$ & [39] \\
\hline \multirow{8}{*}{ Fujian } & \multirow{3}{*}{ Intrusive rocks } & Granite & $187 \mathrm{Ma}$ & [40] \\
\hline & & Gneissic granite & $169-137 \mathrm{Ma}$ & [29] \\
\hline & & Fine-grained granite; alkali-feldspar granite; syenite & $132-87 \mathrm{Ma}$ & [41] \\
\hline & \multirow{3}{*}{ Extrusive rocks } & Basic-acid volcanics & 170 - $162 \mathrm{Ma}$ & [42] \\
\hline & & Basic-acid volcanics & $134-120 \mathrm{Ma}$ & [43] \\
\hline & & Bimodal volcanic; Basic dike swarm & $111-80.7 \mathrm{Ma}$ & [11] \\
\hline & \multirow{2}{*}{ Basic dike swarm } & Mafic rocks & 96 - 87 Ма & [44] \\
\hline & & Mafic rocks & 90 - $87 \mathrm{Mа}$ & [45] \\
\hline
\end{tabular}




\section{Regional Structures}

Regional structures are the intuitive feature of the tectonic movement. The nappes or thrusts are an indicator of compressional setting. During fieldwork, we found a nappe structure in Xiaohe gold mines, Anhui Province. This nappe structure is parallel to the NE-trending Jiangshan-Shaoxing fault zone and thrusts from SE to NW, leading to the Neoproterozoic Jingtan formation $\left(\mathrm{Pt}_{3} j\right)$ overlaying the Middle Jurassic Hongqin formation $\left(\mathrm{J}_{2} h\right)$. Granites formed during the Proterozoic Eon were cut and transported to the present location, in which the root can no longer be seen nowadays. This finding denotes that the nappe structure was large-scale. Late Jurassic thrust structures also outcrop in Jiangxi Province (Figure 4). The NE-trending thrust structure in Lengshuikeng deposit thrusts from NW to SE. Therefore, the Jurassic Daguding $\left(\mathrm{J}_{3} d\right)$ formation was overlaid by the Proterozoic Laohutang formation $\left(\mathrm{Pt}_{3} l\right)$, and synchronous granitic rocks formed (Figure 4). The U-Pb ages of $160.8 \mathrm{Ma}$ for the Daguding formation and 154.3 Ma for the granitic rocks [53] indicate that this thrust structure formed at or after 154.3 Ma. As shown in Figure 5, largescale thrust structures formed in the whole South China during Late Jurassic. Examples of thrust structures include Xiaoxi thrusts in Anhui, Shuikoushan thrusts in Hunan, and Jinzhukeng thrusts in Fujian. These thrust structures indicate that South China underwent an intense compression in late Jurassic.

Metamorphic core complexes, granitic dome structures and graben basins are always related to the extensional settings [54]-[56]. Wugongshan in Jiangxi Province was a Mesozoic granitic dome-type extensional structure (Figure 6(A)) that is composed of metamorphic core complexes [54], the youngest Zircon U-Pb age of Wugongshan granitic dome constrain the final formation time of these metamorphic core complexes at $126.3 \mathrm{Ma}$ [57]. Many other metamorphic core complexes, such as Lushan metamorphic core complex in Jiangxi Province (Figure 6(B)), developed in South China during Early Cretaceous. Zircon U-Pb ages constrain the formation time of these metamorphic core complexes between 133 and $123 \mathrm{Ma}$ [27] [58]. Graben basin is commonly seen in South China during Early Cretaceous, filled by Lower Cretaceous-Upper Cretaceous sediments (Figure 6(C)). This observation indicates that Early Cretaceous was a significant extensional stage in South China, and the zenith of extension was between 135 Ma to 120 Ma.

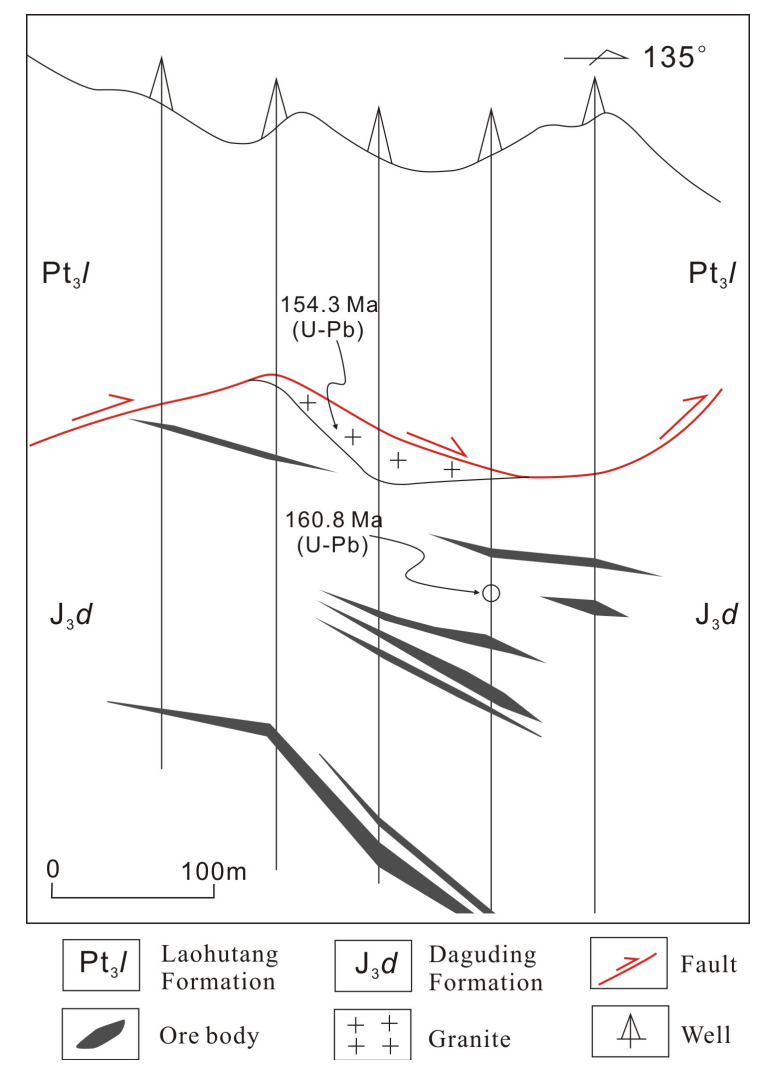

Figure 4. Profile of nappe structure in the Lengshuikeng deposit, Jiangxi province [53]. 


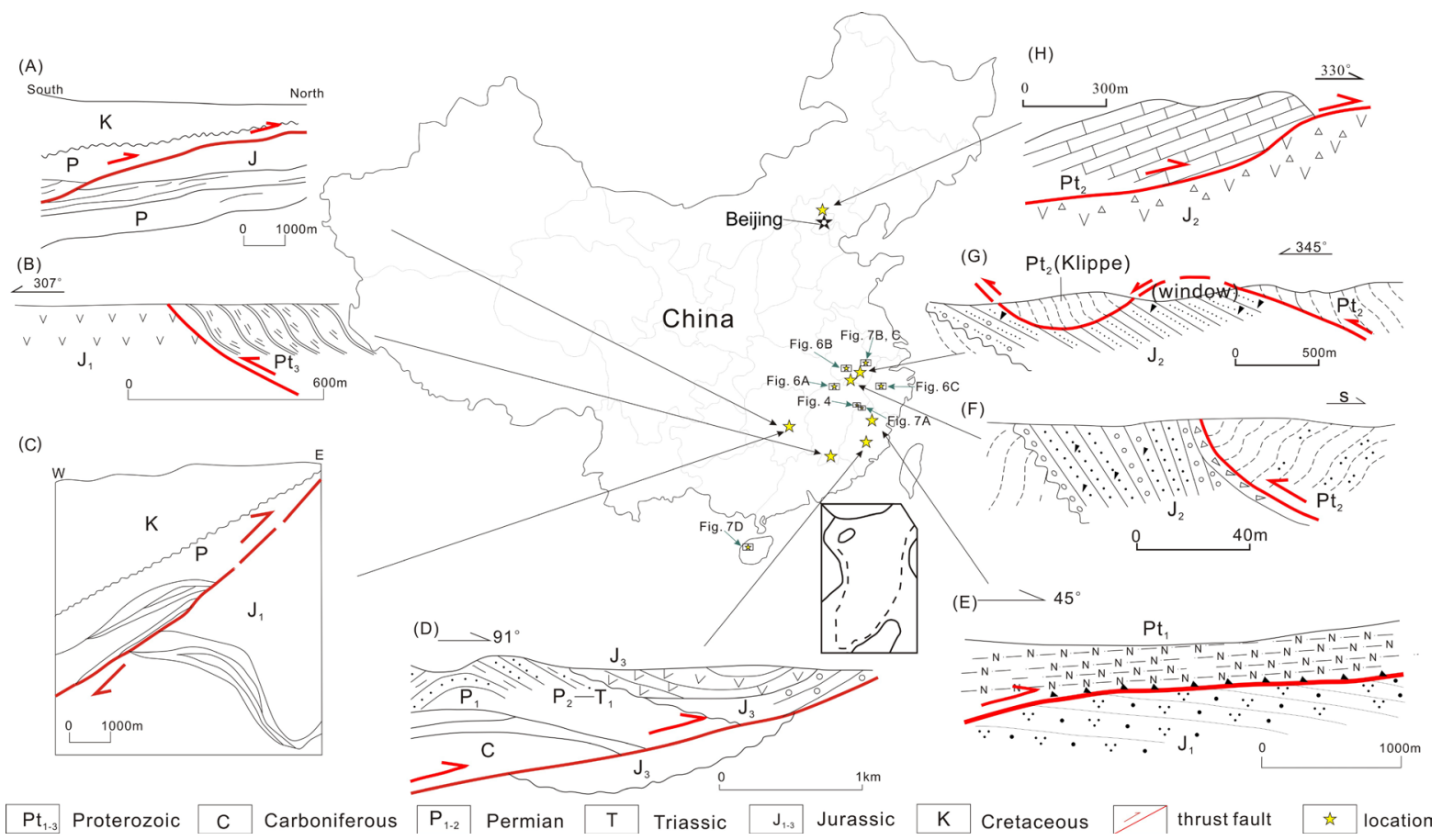

Figure 5. (A) The thrust structure of Shuikoushan deposit, Hunan province [59]; (B) Geological section of Liren to Hangang in Longnan basin, Jiangxi province [25]; (C) The thrust structure of Kangjiawan deposit, Hunan province [59]; (D) Sketch map of the thrust structure in Huangli, Yongan City, Fujian province [60]; (E) The thrust structure of the Jinzhukeng deposit, pucheng county, Fujian province [61]; (F) The thrust structure in Jinzhu village, Xiuning county, Anhui province [62]; (G) Structural window in Xiaoxi Village, Shexian County, Anhui province [63]; (H) Shisanling thrust faulting of Xiyu village, Beijing [48].

Another series of thrusts formed between Early to Late Cretaceous in Southeast China. For example, Mesoproterozoic strata thrust over Jurassic strata in Huangbi, Jiangxi Province, during Middle-Late Jurassic (Figure 7(A)). By contrast, in Early-Late Cretaceous, the Mesoproterozic and Jurassic strata overlay the Early Cretaceous Ehuling formation $\left(\mathrm{K}_{1} e\right.$ ) (Figure $7(\mathrm{~A})$ ). The same phenomenon can be seen in Anhui and Hainan Provinces, where the Mesoproterozoic and Paleozoic overlay the Lower Cretaceous (Figures 7(B)-(D)). Compared with the Late Jurassic thrust structures, the thrust structures formed in Early-Late Cretaceous are smaller in scale.

Basing on the temporal-spatial distribution of igneous rocks, stratigraphic sequence, and regional structures (Figure 9), we can infer that two compressional and three extensional events happened in Southeast China during Late Mesozoic (200 - 80 Ma).

\section{Distribution of Mineral Deposits and Magmatic Oxygen Fugacity}

One of the most important mineralization events occurred in the Mid-Late Jurassic in Southeast China. Numerous $\mathrm{Cu}$-Au-Mo deposits, which are associated with I-type granites, formed during this period [66]. In addition, these ore deposits distributed widely from coastal areas to inland (Figure 8) were probably caused by the subduction of the Paleo-Pacific plate on the Pacific margin [67]-[69]. The Early Cretaceous is also an important metallogenic epoch in which many Cu-Au-Mo deposits formed. For example, the famous Zijinshan Cu-Au deposit formed during $110 \mathrm{Ma}$ to $100 \mathrm{Ma}$ [11]. However, the Early Cretaceous Cu-Au deposits differ from the Late Jurassic deposits because the former deposits are distributed only along the coastal areas (Figure 8). Both the Jurassic and Cretaceous Cu-Au deposits are featured by extremely high magmatic oxygen fugacity [67] [70] [71].

Studies on controlling factors of high fo2 have received much attention for a long time [74] [75]. Ballard et al. [76] reported that the Chuquicamata calc-alkaline intrusions of northern Chile had high magmatic oxygen fugacity, which is probably associated with subduction of plates. Lee et al. [74] found that the oxygen fugacity of arc-related magmas is higher than that formed in other tectonic environments. Wang et al. [75] stressed the influence of subducting oceanic sediments and slab dehydration fluids on magmatic oxygen fugacity through the 


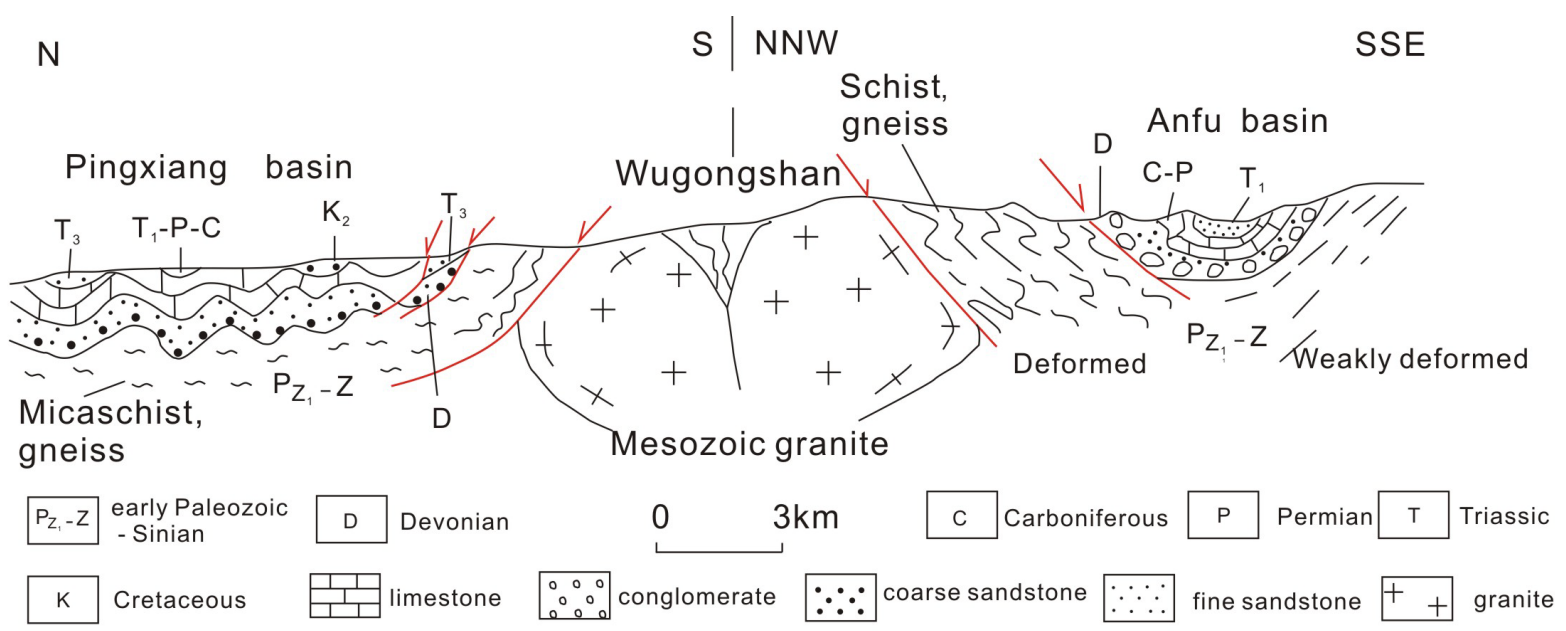

(A)

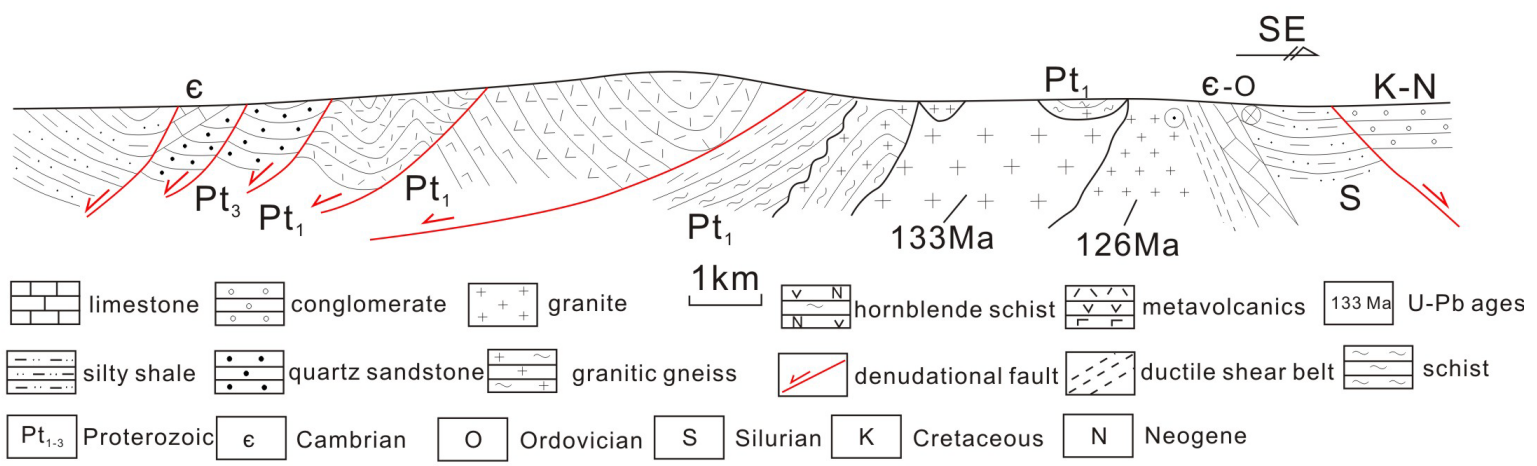

(B)

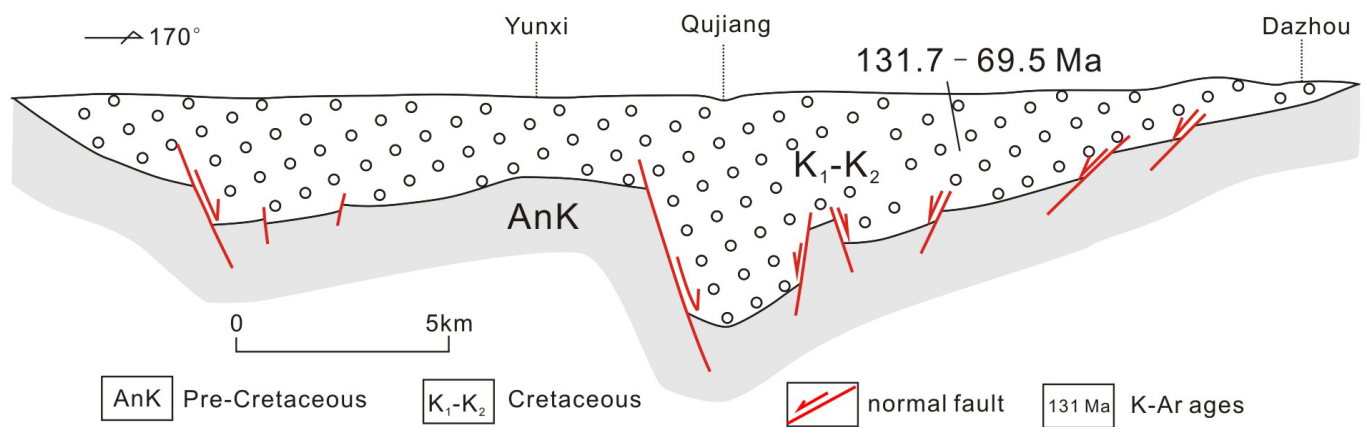

(C)

Figure 6. (A) Geological section through the Wugongshan granitic dome [54]; (B) Cross-sections through the Lushan metamorphic core complex, Jiangxi province [27]; (C) Profile of Jinhua-Quzhou (Jinqu) tectonic basin, Zhejiang province [64] (K-Ar ages from [65]).

study of zircon Hf-O isotopes and trace elements. Therefore, fluids released from subduction slabs were commonly invoked to explain the elevation of oxidation state of the arc lavas. Thus, we concluded that high oxygen fugacity can indicate that magmas formed in a subduction-related setting to a certain extent.

\section{Dynamic Mechanism of Tectonic Evolution}

The tectonic evolution of Southeast China during the Late Mesozoic period has always been a topic of debates [77]-[83]. The following are the mainstream theories regarding this issue: the flat-slab subduction model presented by Li and Li [1]; the slab dip angle of Paleo-Pacific plate subduction underneath Southeast China increased 


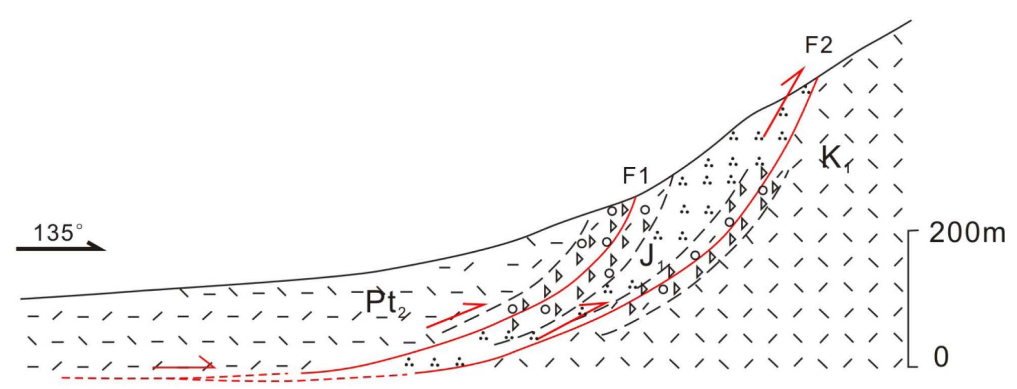

(A)

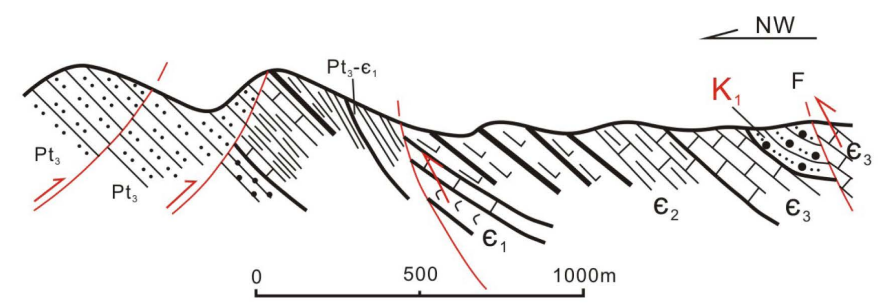

(B)

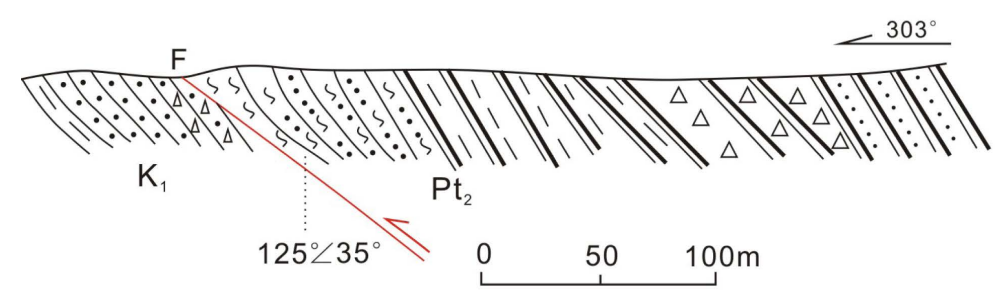

(C)

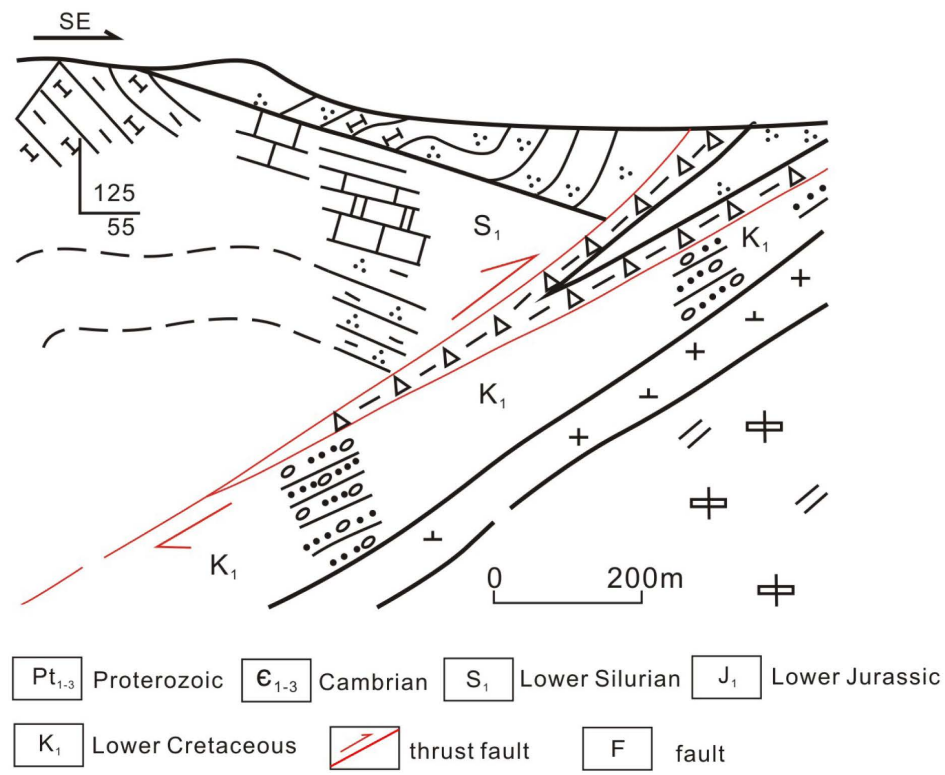

(D)

Figure 7. (A) Thrust structure in the Huangbi deposit, Jiangxi province [72]; (B) Section of the Ningguo-Jixi fault zone, Anhui province [63]; (C) Thrust structure in the Ningguo-Jixi fault zone, Anhui province [63]; (D) Thrust structure in Junying-Hongling tectonic zone, Hainan province [73]. 


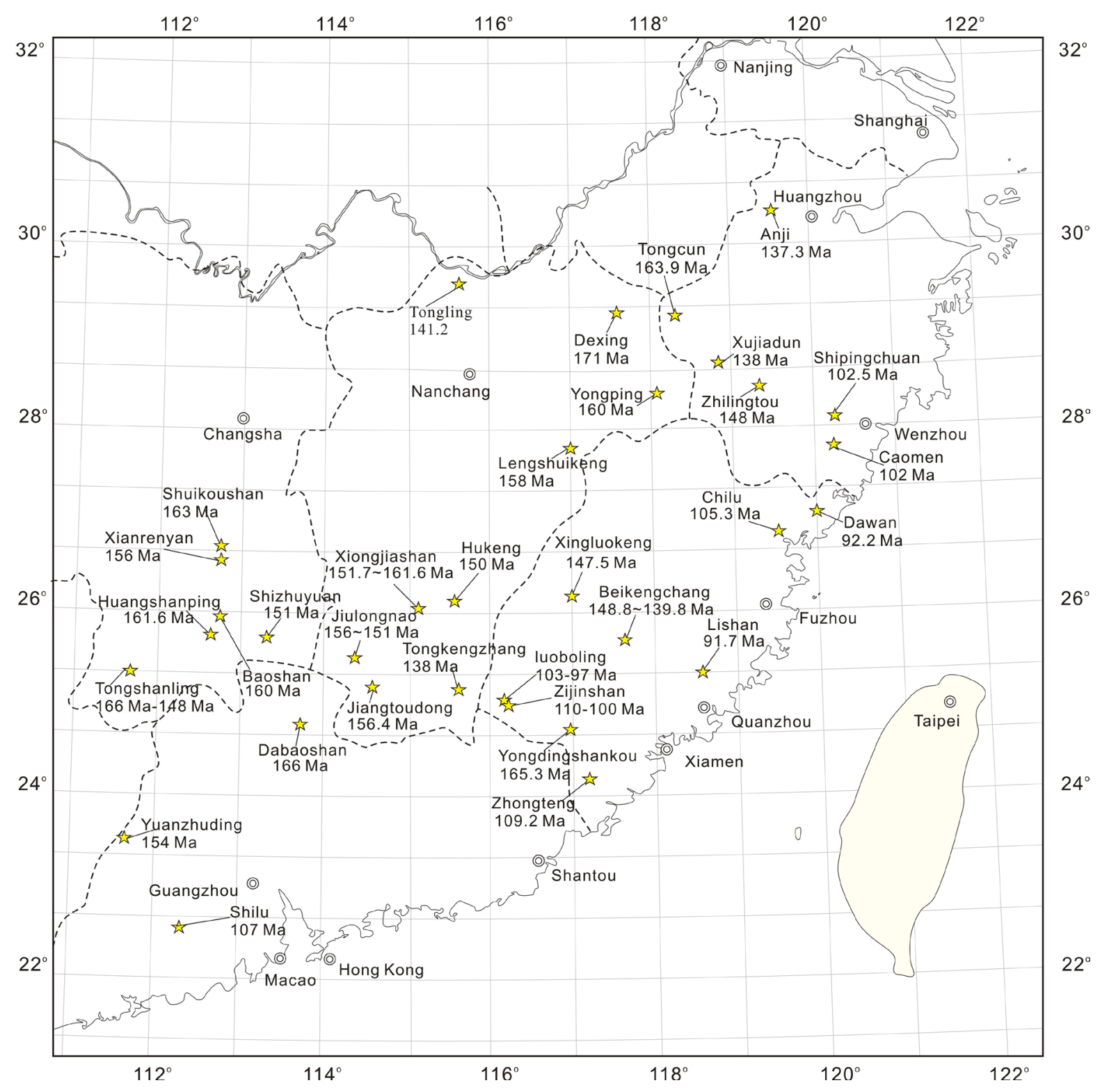

Figure 8. Distribution of $\mathrm{Cu}, \mathrm{Mo}$, and $\mathrm{Au}$ deposits in southeast China.

from a very low angle to a median angle [2]. An important geological event in the flat-slab subduction model shows that the age of synorogenic magmatism represents a trend of younging toward the cratonic interior. However, this event is not evident in South China in Mesozoic magmatism. The increasing slab dip angle model demonstrates a gradual change process. However, the geologic phenomenon is not evident in this gradual change process, which reflects two tectonic events instead. The first event occurred in Late Jurassic and was largescale, thereby leading to the formation of nappe structures, magmatic rocks, and hiatus from coastal to inland areas; the second event occurred in Early Cretaceous and was smaller than the first event. Therefore, the geologic phenomenon in the second event can be seen along the coastal areas. Some small-scaled nappe structures, brief hiatus, and magmatic rocks formed during the second geological event.

The change in the drifting direction of the Paleo-Pacific plate can explain the above geological events (Figure 9). Under the drastic NW-SE compression during Late Jurassic, NE trending nappe structures thrust from SE to NW in Southeast China. The compressional stress came from the southeast of Eastern China. However, no continent is located to the southeast of Eastern China [6]. Consequently, the NW-striking subduction of the Paleo-Pacific plate is the origin of compressional stress. Thus, a series of compressional phenomena formed during 


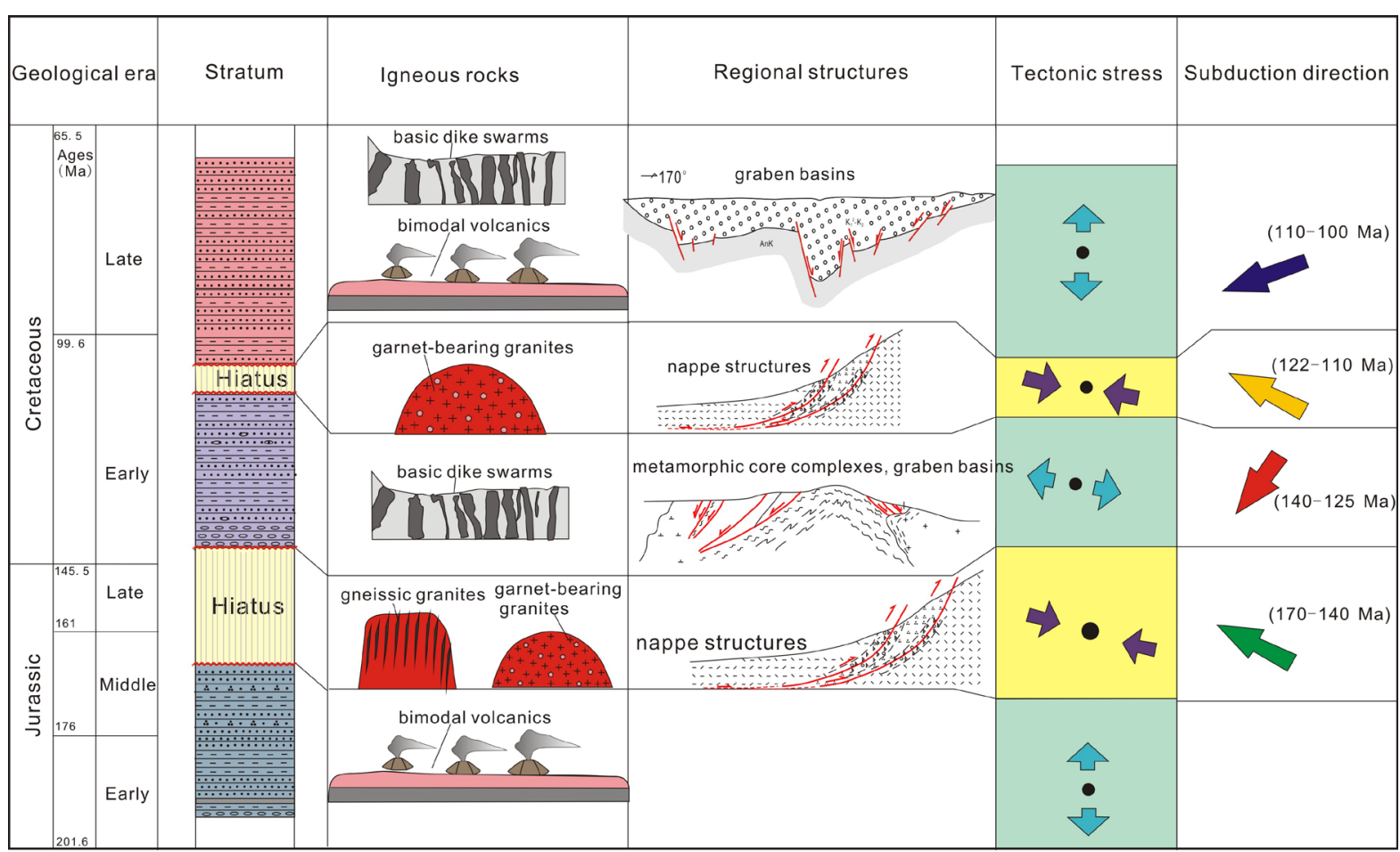

Figure 9. Tectonic evolution diagram of southeast China during Late Mesozoic. (Tectonic stress from [51]; Subduction direction from [84]-[86]).

Middle-Late Jurassic (170 Ma to $145 \mathrm{Ma}$ ). The drifting direction of the Paleo-Pacific plate has changed several times since $140 \mathrm{Ma}$ [84]-[86]. First, the Paleo-Pacific plate moved roughly southward during $140 \mathrm{Ma}$ to $120 \mathrm{Ma}$, with the drifting direction nearly parallel to the east boundary of the Eurasian continent. Therefore, many undeformed granites, alkali granites, metamorphic core complexes, graben basin, and some basic dike swarms formed under the extensional background in Southeast China during Early Cretaceous. Meanwhile, the synchronous widespread volcanic series formed.

The subduction direction changed by $\sim 80^{\circ}$ at $\sim 125$ - 122 Ma and persisted until $110 \mathrm{Ma}$ [86]. Correspondingly, the subduction of the Paleo-Pacific plate turned out to be NW-striking. The second compressional event occurred at 125 Ma to $110 \mathrm{Ma}$, when some nappe structures and a brief hiatus formed.

From $\sim 110 \mathrm{Ma}$ to $\sim 100 \mathrm{Ma}$, the subduction direction changed by $\sim 30^{\circ}$ and changed again by $\sim 75^{\circ}$ at $\sim 100 \mathrm{Ma}$. When the extensional event occurred again in South China during $110 \mathrm{Ma}$ to $80 \mathrm{Ma}$, largescale bimodal volcanics, basic dike swarms, and alkali granites formed.

The subduction direction of the plate varied with time. The Jurassic-Cretaceous tectonic evolution of Southeast China is coupled with the subduction of the Paleo-Pacific plate. With the changes in the subduction direction of the Paleo-Pacific plate, the tectonic evolution demonstrated an alternation between compression and extension, which generated numerous geological events (Figure 9).

\section{Conclusions}

A multistage tectonic evolution history during Late Mesozoic was established, which included the following stages: 1) Early-Middle Jurassic (196 - $175 \mathrm{Ma}$ ) extension, represented by bimodal volcanics; 2) Middle-Late Jurassic (165 - 140 Ma) compression, evidenced by largescale nappe structures; 3) Early Cretaceous (140 \pm 5 $120 \mathrm{Ma}$ ) extension, represented by metamorphic core complexes, graben basins, and some basic dike swarms; 4) Early Cretaceous (120 - $110 \mathrm{Ma}$ ) compression, featured by nappe structures; and 5) Early-Late Cretaceous (110 $80 \mathrm{Ma}$ ) extension, evidenced by largescale bimodal volcanics, basic dike swarms, and graben basins.

The Late Mesozoic tectonic evolution of Southeast China may be attributed to the drifting history of the PaleoPacific plate. The drifting direction of the Paleo-Pacific plate has changed several times since $140 \mathrm{Ma}$, and this may lead to prominently different tectonic phenomena between Jurassic and Cretaceous. 


\section{Acknowledgements}

This work was financially supported by the National Nature Sciences Foundation of China (No. 41272232) and the foundations (No. LYC15-26, JGYQ2015027, WHCY2015B13, XXTYCY2015C01 and 2014RC39). De'en Wang and Dehui Zhang are thanked for their guidance and advices. The author is grateful to the 332 Geological Team of Anhui Bureau of Geology and Mineral Resources for their enthusiastic help.

\section{References}

[1] Li, Z.X. and Li, X.H. (2007) Formation of the 1300-km-Wide Intracontinental Orogen and Postorogenic Magmatic Province in Mesozoic South China: A Flat-Slab Subduction Model. Geology, 35, 179-182. http://dx.doi.org/10.1130/G23193A.1

[2] Zhou, X.M. and Li, W.X. (2000) Origin of Late Mesozoic Igneous Rocks in Southeastern China: Implications for Lithosphere Subduction and Underplating of Mafic Magmas. Tectonophysics, 326, 269-287. http://dx.doi.org/10.1016/S0040-1951(00)00120-7

[3] Zhou, X.M., Sun, T., Shen, W.Z., Shu, L.S. and Niu, Y.L. (2006) Petrogenesis of Mesozoic Granitoids and Volcanic Rocks in South China: A Response to Tectonic Evolution. Episode, 29, 26-33.

[4] Hsü, K.J., Li, J.L., Chen, H.H., Wang, Q.C., Sun, S. and Sengor, A.M.C. (1990) Tectonics of South China-Key to Understanding West Pacific Geology. Tectonophysics, 183, 9-39. http://dx.doi.org/10.1016/0040-1951(90)90186-C

[5] Charvet, J., Shu, L.S., Shi, Y.S., Guo, L.Z. and Faure, M. (1996) The Building of South China: Collision of Yangzi and Cathaysia Block, Problems and Tentative Answers. Journal of Southeast Asian Earth Sciences, 13, 223-235. http://dx.doi.org/10.1016/0743-9547(96)00029-3

[6] Faure, M. and Natal'in, B. (1992) The Geodynamic Evolution of the Eastern Eurasian Margin in Mesozoic Times. Tectonophysics, 208, 397-411. http://dx.doi.org/10.1016/0040-1951(92)90437-B

[7] Gilder, S.A., Keller, G.R., Luo, M. and Goodell, P.C. (1991) Timing and Spatial Distribution of Rifting in China. Tectonophysics, 197, 225-243. http://dx.doi.org/10.1016/0040-1951(91)90043-R

[8] Mao, J.W., Li, H.Y., Wang, D.H. and Peng, C. (1998) Ore-Forming of Mesozoic Polymetallic Deposits in South China and Its Relationship with Mantle Plume. Bulletin of Mineralogy, Petrology and Geochemistry, 17, 130-132.

[9] Li, H.K., Li, Y.F., Geng, K., Zhuo, C.Y., Zhang, Y.B. and Liang, T.T. (2011) Study on the Orogenic Type Gold Deposits in Eastern Shandong Province. Geotectonica et Metallogenia, 35, 533-542.

[10] Li, P.J., Yu, X.Q., Li, H.Y., Qiu, J.T. and Zhou, X. (2013) Jurassic-Cretaceous Tectonic Evolution of Southeast China: Geochronological and Geochemical Constraints of Yanshanian Granitoids. International Geology Review, 55, 12021219. http://dx.doi.org/10.1080/00206814.2013.771952

[11] Jiang, S.H., Liang, Q.L., Bagas, L., Wang, S.H., Nie, F.J. and Liu, Y.F. (2013) Geodynamic Setting of the Zijinshan Porphyry-Epithermal Cu-Au-Mo-Ag Ore System, SW Fujian Province, China: Constrains from the Geochronology and Geochemistry of the Igneous Rocks. Ore Geology Reviews, 53, 287-305. http://dx.doi.org/10.1016/j.oregeorev.2013.02.001

[12] Wang, C.M., Zhang, D., Wu, G.G., Xu, Y.G., Carranza, E.M., Zhang, Y.Y., Li, H.K. and Geng, J.Z. (2013) Zircon U-Pb Geochronology and Geochemistry of Rhyolitic Tuff, Granite Porphyry and Syenogranite in the Lengshuikeng Ore District, SE China: Implications for a Continental Arc to Intra-Arc Rift Setting. Journal of Earth System Science, 122, 809-830. http://dx.doi.org/10.1007/s12040-013-0302-2

[13] Qiu, J.T., Song, W.J., Jiang, C.X., Wu, H. and Dong, R.M. (2013) CGDK: An Extensible Corel DRAW VBA Program for Geological Drafting. Computers \& Geosciences, 51, 34-48. http://dx.doi.org/10.1016/j.cageo.2012.07.020

[14] Xu, W.L., Wang, D.Y., Liu, X.C., Wang, Q.H. and Lin, J.Q. (2002) The Discovery of Eclogite Enclave in Early Jurassic Intrusive Rocks of Xuhuai Region and Its Geological Implications. Chinese Science Bulletin, 47, 618-622. http://dx.doi.org/10.1007/BF02907612

[15] Hu, F.F., Fan, H.R., Yang, J.H., Wan, Y.S., Liu, D.Y., Zhai, M.G. and Jin, C.W. (2004) Mineralizing Age of the Rushan Lode Gold Deposit in the Jiaodong Peninsula: SHRIMP U-Pb Dating on Hydrothermal Zircon. Chinese Science Bulletin, 49, 1629-1636. http://dx.doi.org/10.1007/BF03184134

[16] Li, Y., Han, F., Ling, M.X., Liu, J., Li, X.H., Li, Q.L. and Sun, W.D. (2010) Geochronology, Geochemical Characteristics and Geodynamic Significance of the Jingshan and Tushan Granites in the Bengbu Uplift. Geotectonica Et Metallogenia, 34, 114-124.

[17] Yang, D.B., Xu, W.L., Pei, F.P., Wang, Q.H. and Liu, X.M. (2005) Formation Time and Magma Source of Granites in Bengbu Uplift: Evidence from LA-ICPMS Zircon U-Pb Dating and Tracing. Geochimica, 34, 443-454.

[18] Xie, C.L., Zhu, G., Niu, M.L. and Wang, Y.S. (2007) LA-ICP MS Zircon U-Pb Ages of the Mesozoic Volcanic Rocks 
from Chuzhou Area and Their Tectonic Significances. Geology Reviews, 53, 642-655.

[19] Zhou, X., Yu, X.Q., Wang, D.E., Zhang, D.H., Li, C.L., Fu, J.Z. and Dong, H.M. (2011) Characteristics and Geochronology of the W, Mo-Bearing Granodiorite Porphyry in Dongyuan, Southern Anhui. Geoscience, 25, 201-210.

[20] Wu, F.Y., Ji, W.Q., Sun, D.H., Yang, Y.H. and Li, X.H. (2012) Zircon U-Pb Geochronology and Hf Isotopic Compositions of the Mesozoic Granites in Southern Anhui Province, China. Lithos, 150, 6-25. http://dx.doi.org/10.1016/j.lithos.2012.03.020

[21] Li, D.W. (1993) Geological Characteristics and Metallogenic Significance of Hongzhen Metamorphic Core Complexes, Anhui. Geotectonica Et Metallogenia, 17, 211-220.

[22] He, Z.Y., Xu, X.S. and Niu, Y.L. (2010) Petrogenesis and Tectonic Significance of a Mesozoic Granite-Syenite-Gabbro Association from Inland South China. Lithos, 119, 621-641. http://dx.doi.org/10.1016/j.lithos.2010.08.016

[23] Zhou, Q., Jiang, Y.H., Zhao, P., Liao, S.Y. and Jin, G.D. (2012) Origin of the Dexing Cu-Bearing Porphyries, SE China: Elemental and Sr-Nd-Pb-Hf Isotopic Constraints. International Geology Review, 54, 572-592. http://dx.doi.org/10.1080/00206814.2010.548119

[24] Yang, S.Y., Jiang, S.Y., Jiang, Y.H., Zhao, K.D. and Fan, H.H. (2011) Geochemical, Zircon U-Pb Dating and Sr-NdHf Isotopic Constraints on the Age and Petrogenesis of an Early Cretaceous Volcanic-Intrusive Complex at Xiangshan, Southeast China. Mineralogy and Petrology, 101, 21-48. http://dx.doi.org/10.1007/s00710-010-0136-4

[25] Ji, C.Y. and Wu, J.H. (2010) The SHRIMP Zircon U-Pb Dating of Felsic Volcanic Rocks and Its Geological Significance from Yutian Group in Southern Jiangxi. Journal of East China Institute of Technology, 33, 131-138.

[26] Wu, J.H., Xu, X.S. and Liu, S. (2012) SHRIMP Zircon U-Pb Dating of the Early Late Cretaceous Felsic Volcanic Rock in Southern Jiangxi-Northern Guangdong Area and Its Geological Significance. Geological Bulletin of China, 31, 1296-1305.

[27] Zhu, Q.B., Yang, K.G. and Wang, Y. (2010) Extensional Detachment and Magmatism of the Lushan Metamorphic Core Complex: Constraints from 40Ar/39Ar and U-Pb Geochronology. Geotectonica Et Metallogenia, 34, 391-401.

[28] Yu, X.Q., Di, Y.J., Wu, G.G., Zhang, D., Zheng, Y. and Dai, Y.P. (2009) The Early Jurassic Magmatism in Northern Guangdong Province, Southeastern China: Constraints from SHRIMP Zircon U-Pb Dating of Xialan Complex. Science in China Series D: Earth Sciences, 39, 681-693. http://dx.doi.org/10.1007/s11430-009-0038-7

[29] Cui, J.J., Zhang, Y.Q., Dong, S.W., Jahn B.M., Xu, X.B. and Ma, L.C. (2013) Zircon U-Pb Geochronology of the Mesozoic Metamorphic Rocks and Granitoids in the Coastal Tectonic Zone of SE China: Constraints on the Timing of Late Mesozoic Orogeny. Journal of Asian Earth Sciences, 62, 237-252. http://dx.doi.org/10.1016/j.jseaes.2012.09.014

[30] Wu, J.H., Liu, F.Y. and Liu, S. (2011) SHRIMP U-Pb Zircon Age of Late Mesozoic Trachyte in Xiajiang-Guangfeng and Sannan (Quannan, Dingnan and Longnan)-Xunwu Volcanic Belts. Geology Reviews, 57, 125-132.

[31] Yu, X.Q., Wu, G.G., Di, Y.J., Qiu, J.T. and Zhou, X. (2010) SHRIMP Zircon U-Pb Dating of the Early Jurassic Magmatic Rocks in Dongkeng Basin, South Jiangxi Province, and the Later Tectonothermal Events in Southern Jiangxi and Northern Guangdong Provinces. Acta Petrologica Sinica, 26, 3469-3484.

[32] Ding, X., Chen, P.R., Chen, W.F., Huang, H.Y. and Zhou, X.M. (2005) LA-ICPMS U-Pb Zircon Dating of Weishan Granite in Hunan and Its Geological Significance. Science in China (Series D), 35, 606-616.

[33] Wang, D.H., Li, H.Q., Qin, Y., Mei, Y.P., Chen, Z.H., Qu, W.J., Wang, Y.B., Cai, H., Gong, S.Q. and He, X.P. (2009) Rock-Forming and Ore-Forming Ages of the Yaogangxian Tungsten Deposit of Hunan Province. Rock and Mineral Analysis, 28, 201-208.

[34] Wang, L.X., Ma, C.Q., Zhang, J.Y., Chen, L. and Zhang, C. (2008) Petrological and Geochemical Characteristics and Petrogenesis of the Early Cretaceous Taohuashan-Xiaomoshan Granites in Northeastern Hunan Province. Journal of China University of Geosciences, 14, 334-349.

[35] Ma, T.Q., Yan, Q.R., Chen, H.M., Xiang, Z.J., Zhou, K.J. and Li, B. (2012) The Zircon LA-ICP-MS U-Pb Ages and Geochemistry Features of Basalt at Xinshi, Youxian, Hunan Province. Geology and Mineral Resources of South China, 28, 340-349.

[36] Liu, L., Xu, X.S. and Zou, H.B. (2012) Episodic Eruptions of the Late Mesozoic Volcanic Sequences in Southeastern Zhejiang, SE China: Petrogenesis and Implications for the Geodynamics of Paleo-Pacific Subduction. Lithos, 154, 166180. http://dx.doi.org/10.1016/j.lithos.2012.07.002

[37] Chen, C.H., Lee, C.Y., Lub, H.Y. and Hsieh, P.S. (2008) Generation of Late Cretaceous Silicic Rocks in SE China: Age, Major Element and Numerical Simulation Constraints. Journal of Asian Earth Sciences, 31, 479-498. http://dx.doi.org/10.1016/j.jseaes.2007.08.002

[38] Li, F.L., Zhou, H.W., Tang, Z.C., Li, Y.L., Wang, F.X., Xu, Y.C., Qin, H.F., Luo, W. and Guan, C.G. (2011) U-Pb Ages, Geochemistry and Tectonic Implications of Mafic Dyke Swarms in Mugua, Chun'an County, Zhejiang Province. Geochimica, 40, 22-34.

[39] Dong, C.W., Yan, Q., Zhang, D.R., Du, Z.Y. and Zhu, G.Q. (2010) Late Mesozoic Extension in the Coastal Area of 
Zhejiang and Fujian Province: A Petrologic Indicator from the Dongji Island Mafic Dike Swarms. Acta Petrologica Sinica, 26, 1195-1203.

[40] Liu, Q., Yu, J.H., Su, B., Wang, Q., Tang, H.F., Xu, H. and Cui, X. (2011) Discovery of the 187Ma Granite in Jincheng Area, Fujian Province: Constraint on Early Jurassic Tectonic Evolution of Southeastern China. Acta Petrologica Sinica, 27, 3575-3589.

[41] He, Z.Y. and Xu, X.S. (2012) Petrogenesis of the Late Yanshanian Mantle-Derived Intrusions in Southeastern China: Response to the Geodynamics of Paleo-Pacific Plate Subduction. Chemical Geology, 328, 208-221. http://dx.doi.org/10.1016/j.chemgeo.2011.09.014

[42] Deng, P., Shu, L.S., Yu, X.Q., Wang, B., Tan, Z.Z. and Sun, Y. (2004) Early-Middle Jurassic Basins and Features of Igneous Rocks in the Western Fujian-Southern Jiangxi Region. Acta Petrologica Sinica, 20, 521-532.

[43] Zheng, K.L. (2012) New Researching Development of Late Mesozoic Volcano Formation in Fujian Province. Geology of Fujian, 31, 325-335.

[44] Yang, Y.F., Yang, J.J., Li, N.M., Yan, Q., Zhan, X. and Dong, C.W. (2010) SHRIMP U-Pb Zircon Dating of the Basic-Intermediate Dikes from the Coastland of Fujian Province. Geological Science and Technology Information, 29, 23-29.

[45] Dong, C.W., Zhang, D.R., Xu, X.S., Yan, Q. and Zhu, G.Q. (2006) SHRIMP U-Pb Dating and Lithogeochemistry of Basic-Intermediate Dike Swarms from Jinjiang, Fujian Province. Acta Petrologica Sinica, 22, 1696-1702.

[46] Pearce, J.A., Harris, N.B.W. and Tindle, A.G. (1984) Trace Element Discrimination Diagrams for the Tectonic Interpretation of Granitic Rocks. Journal of Petrology, 25, 956-983. http://dx.doi.org/10.1093/petrology/25.4.956

[47] Chappell, B.W. (1999) Aluminium Saturation in I and S-Type Granites and the Characterization of Fractionated Haplogranites. Lithos, 46, 535-551. http://dx.doi.org/10.1016/S0024-4937(98)00086-3

[48] Deng, J.F., Su, S.G., Zhao, G.C. and Liu, C. (2004) Structural Elements Association of Yanshan Orogenic Belt, North China. Journal of China University of Geosciences, 10, 315-323.

[49] Wu, F.Y., Li, X.H., Yang, J.H. and Zheng, Y.F. (2007) Discussions on the Petrogenesis of Granites. Acta Petrologica Sinica, 23, 1217-1238.

[50] Barbarin, B. (1999) A Review of the Relationships between Granitoid Types, Their Origins and Their Geodynamic Environments. Lithos, 46, 605-626. http://dx.doi.org/10.1016/S0024-4937(98)00085-1

[51] Zhang, Y.Q., Dong, S.W., Li, J.H., Cui, J.J., Shi, W., Su, J.B. and Li, Y. (2012) The New Progress in the Study of Mesozoic Tectonics of South China. Acta Geologica Sinica, 33, 257-279.

[52] Li, W., Dong, Y.P., Guo, A.L., Liu, X.M., Liu, Y.Q., Zha, X.F. and Zhang, K.L. (2013) Sedimentary Fill History of the Huicheng Basin in the West Qinling Mountains and Associated Constraints on Mesozoic Intracontinental Tectonic Evolution. Science China Earth Sciences, 56, 1639-1653. http://dx.doi.org/10.1007/s11430-013-4607-4

[53] Qiu, J.T., Yu, X.Q., Wu, G.G., Liu, J.G. and Xiao, M.Z. (2013) Geochronology of Igneous Rocks and Nappe Structures in Lengshuikeng Deposit, Jiangxi Province, China. Acta Petrologica Sinica, 29, 812-826.

[54] Shu, L.S., Sun, Y., Wang, D.C., Faure, M., Monie, P. and Charvet, J. (1998) Mesozoic Doming Extensional Tectonics of Wugongshan, South China. Science in China (Series D), 416, 601-608.

[55] Qi, J.F. and Yang, Q. (2012) Dynamic Analysis of Continental Rifting Basin. Earth Science Frontiers, 19, 19-26.

[56] Li, L., Zhong, D.L., Yang, C.C., Shi, X.P., Hu, Q.Y., Zhao, L., Sun, Y.H. and Liu, H. (2012) Extension Order and Its Deep Geological Background: Evidence from Western Shandong Rise and Jiyang Depression in the Late MesozoicCenozoic. Earth Science Frontiers, 19, 255-273.

[57] Lou, F.S., Shen, W.Z., Wang, D.Z., Shu, L.S., Wu, F.J., Zhang, F.R. and Yu, J.H. (2005) Zircon U-Pb Isotopic Chronology of the Wugongshan Dome Compound Granite in Jiangxi Province. Acta Geologica Sinica, 79, 636-644.

[58] Li, X.G., Yang, K.G. and Zhu, Q.B. (2010) Zircon LA-ICP-MS U-Pb Dating of Granitic Intrusion in the Core of Lushan Metamorphic Core Complex and Its Geological Significance. Journal of Mineralogy and Petrology, 30, 36-42.

[59] Gao, X.D. (1995) Main Types of Gold Deposit in Shuikoushan Ore Field and the Prospective Areas for Au-Searching. Hunan Geology, 14, 220-225.

[60] Guan, Y.X. and Yang, T.S. (1994) Nappe Structure Research of Fujian Province and Its Significance. Geology of Fujian, 13, 248-276.

[61] Yu, X.Q., Wu, G.G., Zhang, D., Di, Y.J., Dai, Y.P. and Qiu, J.T. (2008) Thrust Nappe Structure and Its Ore-Controlling Effects in the North Wuyi Area, China. Geological Bulletin of China, 27, 1667-1677.

[62] Yu, X.Q., Zhang, D., Wang, L.W., Yan, T.Z. and Deng, G.H. (2006) Features of Caledonian Tectonic Deformation in the Zhejiang-Anhui-Jiangxi Border Region, China. Geological Bulletin of China, 25, 676-684. 
[63] Yu, X.Q., Jiang, L.L., Xu, W., Qiu, R.L., Du, J.G. and Dai, S.Q. (2007) Identification and Basic Characteristics of the Anhui-Zhejiang-Jiangxi Fault Zone. Earth Science Frontiers, 14, 102-113.

[64] Yu, X.Q., Shu, L.S., Yan, T.Z. and Zu, F.P. (2005) Prototype and Sedimentation of Red Basins along the Ganhang Tectonic Belt. Acta Sedimentologica Sinica, 23, 12-20.

[65] Qi, Y.Q., Hu, R.Z., Liu, S., Feng, C.X., Tian, J.J., Feng, G.Y. and Wang, T. (2011) Geochemical Characteristics of the Yanshanian Mafic Dykes in the Jinqu Basin, Gan-Hang Tectonic Belt and Its Petrogenesis. Acta Geologica Sinica, 85, 354-365.

[66] Mao, J.W., Cheng, Y.B., Chen, M.H. and Franco, P. (2013) Major Types and Time-Space Distribution of Mesozoic Ore Deposits in South China and Their Geodynamic Settings. Mineralium Deposita, 48, 267-294. http://dx.doi.org/10.1007/s00126-012-0446-Z

[67] Qiu, J.T., Yu, X.Q., Santosh, M., Zhang, D.H., Chen, S.Q. and Li, P.J. (2013) Geochronology and Magmatic Oxygen Fugacity of the Tongcun Molybdenum Deposit, Northwest Zhejiang, SE China. Mineralium Deposita, 48, 545-556. http://dx.doi.org/10.1007/s00126-013-0456-5

[68] Di, Y.J., Xu, Y.G., Wu, G.G., Zhang, D., Xiao, M.Z., Lai, S.H., Yu, X.Q., Qin, S.T., Yan, P.C., Gong, Y. and Qin, X.F. (2013) The Formation Era of Nappe Structure in Lengshuikeng Ag-Pb-Zn Ore Field, Jiangxi: Constraints from Geochronology. Earth Science Frontiers, 20, 340-349.

[69] Chu, K.L., Mao, J.W., Chen, M.H., Zhao, J., Yu, C.F., Lin, L.Z. and Lin, X.G. (2013) Source of Metallogenic Materials and Ore-Forming Fluids, and Metallogenic Mechanism of the Yuanzhuding Porphyry Cu-Mo Deposit, Western Guangdong Province, South China. Earth Science Frontiers, 20, 115-125.

[70] Zhang, H., Ling, M.X., Liu, Y.L., Tu, X.L., Wang, F.Y., Li, C.Y., Liang, H.Y., Yang, X.Y., Arndt, N.T. and Sun, W.D. (2013) High Oxygen Fugacity and Slab Melting Linked to Cu Mineralization: Evidence from Dexing Porphyry Copper Deposits, Southeastern China. Journal of Geology, 121, 289-305. http://dx.doi.org/10.1086/669975

[71] Huang, W.T., Li, J., Liang, H.Y., Wang, C.L., Lin, S.P., Wang, X.Z. (2013) Zircon LA-ICP-MS U-Pb Ages and Highly Oxidized Features of Magma Associated with Luoboling Porphyry Cu-Mo Deposit in Zijinshan Ore Field, Fujian Province. Acta Petrologica Sinica, 29, 283-293.

[72] Qiu, J.T., Yu, X.Q., Wu, G.G., Qu, W.J., Di, Y.J., Zhang, D., Luo, P. and Du, A.D. (2011) Research on the Nappe Structure and Its Relevance to the Mineralization in the Huangbi Deposit, North Wuyi, Southeast China. Earth Science Frontiers, 18, 243-255.

[73] Chen, M.L., Li, S.X. and Zeng, Y.L. (2009) Characteristics of Yanshanian Thrust Nappe Structures in Western Hainan. Mineral Resources and Geology, 23, 104-109.

[74] Lee, C.T.A., Leeman, W.P., Canil, D. and Li, Z.X.A. (2005) Similar V/Sc Systematics in MORB and Arc Basalts: Implications for the Oxygen Fugacities of Their Mantle Source Regions. Journal of Petrology, 46, 2313-2336. http://dx.doi.org/10.1093/petrology/egi056

[75] Wang, F.Y., Liu, S.A., Li, S.G. and He, Y.S. (2013) Contrasting Zircon Hf-O Isotopes and Trace Elements between Ore-Bearing and Ore-Barren Adakitic Rocks in Central-Eastern China: Implications for Genetic Relation to $\mathrm{Cu}-\mathrm{Au}$ Mineralization. Lithos, 156-159, 97-111. http://dx.doi.org/10.1016/j.lithos.2012.10.017

[76] Ballard, J.R., Palin, J.M. and Campbell, I.H. (2002) Relative Oxidation States of Magmas Inferred from Ce(IV)/Ce(III) in Zircon: Application to Porphyry Copper Deposits of Northern Chile. Contributions to Mineralogy and Petrology, 144, 347-364. http://dx.doi.org/10.1007/s00410-002-0402-5

[77] Charvet, J., Lapierre, H. and Yu, Y.W. (1994) Geodynamic Significance of the Mesozoic Volcanism of Southeastern China. Journal of Southeast Asian Earth Sciences, 9, 387-396. http://dx.doi.org/10.1016/0743-9547(94)90050-7

[78] Wang, D.Z. and Shu, L.S. (2012) Late Mesozoic Basin and Range Tectonics and Related Magmatism in Southeast China. Geoscience Frontiers, 3, 109-124. http://dx.doi.org/10.1016/j.gsf.2011.11.007

[79] Zhou, J., Xu, S.F., Chi, Q.H., Chen, E.K., Zhang, B.M. and Wang, W. (2012) Geochemical Characteristics of the Mesozoic Volcanic Belt in Southeast Coast of China. Earth Science Frontiers, 19, 93-100.

[80] Liu, J.Q., Xie, Y., Zhao, Z., Lin, J.S., Feng, W.M. and Huang, X.P. (2013) The Geochronologic Characteristics of Baimashan Granite in Western Hunan Province and Its Geotectonic Significance. Earth Science Frontiers, 20, 25-35.

[81] Charvet, J. (2013) Late Paleozoic-Mesozoic Tectonic Evolution of SW Japan: A Review-Reappraisal of the Accretionary Orogeny and Revalidation of the Collisional Model. Journal of Asian Earth Sciences, 72, 88-101. http://dx.doi.org/10.1016/j.jseaes.2012.04.023

[82] Savva, D., Pubellier, M., Franke, D., Chamot-Rooke, N., Meresse, F., Steuer, S. and Auxietre, J.L. (2014) Different Expressions of Rifting on the South China Sea Margins. Marine and Petroleum Geology, 58, 579-598. http://dx.doi.org/10.1016/j.marpetgeo.2014.05.023

[83] Barckhausen, U., Engels, M., Franke, D., Ladage, S. and Pubellier, M. (2014) Evolution of the South China Sea: Re- 
vised Ages for Breakup and Seafloor Spreading. Marine and Petroleum Geology, 58, 599-611. http://dx.doi.org/10.1016/j.marpetgeo.2014.02.022

[84] Koppers, A.A.P., Morgan, J.P., Morgan, J.W. and Staudigel, H. (2001) Testing the Fixed Hotspot Hypothesis Using 40Ar/39Ar Age Progressions along Seamount Trails. Earth and Planetary Science Letters, 185, 237-252. http://dx.doi.org/10.1016/S0012-821X(00)00387-3

[85] Sharp, W.D. and Clague, D.A. (2006) 50-Ma Initiation of Hawaiian-Emperor Bend Records Major Change in Pacific Plate Motion. Science, 313, 1281-1284. http://dx.doi.org/10.1126/science.1128489

[86] Sun, W.D., Ding, X., Hu, Y.H. and Li, X.H. (2007) The Golden Transformation of the Cretaceous Plate Subduction in the West Pacific. Earth and Planetary Science Letters, 262, 533-542. http://dx.doi.org/10.1016/j.epsl.2007.08.021

[87] Li, P.J. (2014) The Characteristics and Oxygen Fugacity of Yanshanian Igneous Rocks and Regional Tectonic Evolution in Neighboring Sections of Zhejiang, Jiangxi, and Anhui Provinces. PhD Thesis, China University of Geosciences (Beijing), Beijing, 95-99. 